\title{
Pengaruh Perbandingan Tempe Kedelai dan Tepung Terigu Terhadap Mutu Organoleptik Stik Keju Tempe
}

\author{
Mirza Yasinta, Laili Hidayati, Issutarti \\ Universitas Negeri Malang, Jl. Semarang No. 5 Malang, Jawa Timur, Indonesia \\ *Penulis korespondensi, Surel: laili.hidayati.ft@um.ac.id
}

Paper received: 05-02-2021; revised: 18-02-2021; accepted: 30-02-2021

\begin{abstract}
Tempe cheese stick is a snack which is made of cheese stick that is produced by using a different ratio between tempe and wheat flour as its main ingredients. This product is aimed to formulate a tempeflavoured snack which catches up with the current trend in the food industry, so it can reach a wider market as an alternative option for a souvenir. The purpose of this research is to analyse the hedonic quality and hedonic index over colour, taste, and texture of the tempe cheese stick with different proportions of tempe and wheat flour. This research employs fully randomised design methods to conduct experiments by using one deciding factor which is the proportion of wheat flour and tempe (60 percent: 40 percent, 45 percent:55 percent and 30 percent:70 percent) and it is done twice. The data is analysed by using One Way ANOVA. If there is a contrast in the colour, DMRT test is conducted successively. The result shows that there is a significant difference in the hedonic quality of colour and texture of tempe cheese stick according to the variation in the proportion of tempe and wheat flour, however, this variation does not quite affect the hedonic quality of taste. Consequently, there is a clear difference in the measured taste and texture hedonic index of the tempe cheese stick according to the wheat flour and tempe proportion change, while the colour hedonic quality is relatively unaffected.
\end{abstract}

Keywords: sticks; tempe; wheat flour; hedonic quality; hedonic index

\begin{abstract}
Abstrak
Stik keju tempe merupakan makanan ringan yang dibuat dari stik keju dengan menggunakan tempe dan terigu dengan perbandingan yang berbeda. Produk ini dibuat dengan maksud untuk membuat snack atau makanan ringan rasa tempe yang bisa diterima banyak orang dengan rasa jaman sekarang dan sebagai oleh-oleh. Tujuan penelitian ini adalah untuk menganalisis mutu hedonik dan tingkat kesukaan (hedonik) terhadap warna, rasa dan tekstur stik keju tempe dengan perbandingan tepung terigu dan tempe yang berbeda. Metode penelitian yang digunakan yaitu penelitian eksperimen dengan Rancangan Acak Lengkap (RAL) menggunakan satu faktor yaitu perbandingan tepung terigu dan tempe (60 persen:40 persen, 45 persen:55 persen dan 30 persen:70 persen) dan diulang sebanyak dua kali. Data dianalisis dengan One Way ANOVA. Apabila terdapat perbedaan yang nyata maka dilakukan uji lanjut DMRT. Hasil penelitian menunjukkan bahwa terdapat perbedaan yang nyata pada mutu hedonik warna dan tekstur stik keju tempe dengan perbandingan tepung terigu dan tempe yang berbeda, sedangkan pada mutu hedonik rasa tidak berbeda nyata. Terdapat perbedaan yang nyata pada tingkat kesukaan rasa dan tekstur stik keju tempe dengan perbandingan tepung terigu dan tempe yang berbeda, sedangkan tingkat kesukaan warna stik keju tempe tidak berbeda nyata.
\end{abstract}

Kata kunci: stik; tempe kedelai; tepung terigu; mutu hedonic; tingkat kesukaan

\section{Pendahuluan}

Stik adalah makanan ringan yang penyelesaiannya dengan cara digoreng (Pratiwi, 2013). Stik lebih banyak dipilih sebagai camilan karena tidak terlalu mengenyangkan. Stik yang umum di pasaran yaitu stik keju. Stik keju adalah makanan ringan yang dibuat dari keju. 
Tempe merupakan olahan dari kacang kedelai yang diproses melalui fermentasi (Badan Standardisasi Nasional, 2015). Tempe mengandung protein yang tinggi sehingga memiliki rasa yang gurih. Dalam 100 gram tempe, protein yang terkandung sebanyak 20,8 gram (Departemen Kesehatan, 2018). Tempe biasanya diolah sebagai pendamping nasi. Selain sebagai pendamping nasi, tempe juga dapat diolah menjadi olahan lain yaitu sebagai stik. Stik keju tempe dibuat dari stik keju dengan menggunakan tempe dan terigu dengan perbandingan yang berbeda.

Penelitian ini menggunakan tempe dan tepung terigu sebagai bahan dalam pembuatan stik, dengan perbandingan yang berbeda. Tujuan penelitian ini adalah untuk menganalisis mutu hedonik dan tingkat kesukaan (hedonik) stik keju tempe dengan perbandingan tepung terigu dan tempe yang berbeda terhadap warna, rasa dan tekstur. Selain itu pembuatan stik keju tempe dimaksudkan untuk membuat makanan ringan rasa tempe yang bisa diterima banyak orang.

\section{Metode}

\subsection{Rancangan Penelitian}

Jenis penelitian yang digunakan dalam pembuatan stik tempe kedelai adalah penelitian eksperimen. Rancangan percobaan yang digunakan adalah Rancangan Acak Lengkap (RAL), dengan satu faktor, yaitu perbandingan tepung terigu dan tempe kedelai dengan 3 tingkatan (tepung terigu : tempe kedelai yaitu 60\%:40\%, 45\%:55\% dan 30\%:70\%) dan diulang sebanyak dua kali. Ketiga perlakuan kemudian dianalisis uji organoleptik yang terdiri dari uji mutu hedonik dan uji hedonik (tingkat kesukaan).

Bahan yang digunakan dalam penelitian ini terdiri dari tepung terigu, tempe kedelai, tepung tapioka, garam, keju cheddar, garam dan margarin. Alat yang digunakan dalam penelitian ini terdiri dari timbangan digital, pisau, dandang pengukus, talenan, wajan, kompor, mesin pasta, baskom ukuran sedang, sendok, mangkuk, cobek dan ulekan. Formula stik keju tempe dapat dilihat pada Tabel 1.

Tabel 1. Formula Stik Keju Tempe

\begin{tabular}{lcccc}
\hline \multicolumn{1}{c}{ Bahan } & $\begin{array}{c}\text { Formula } \\
\text { Dasar }\end{array}$ & $\begin{array}{c}\text { Formula 1 } \\
\mathbf{6 0 \% : 4 0 \%}\end{array}$ & $\begin{array}{c}\text { Formula 2 } \\
\mathbf{4 5 \% : 5 5 \%}\end{array}$ & $\begin{array}{c}\text { Formula 3 } \\
\mathbf{3 0 \% : 7 0 \%}\end{array}$ \\
\hline Tepung terigu protein & 250 gram & 150 gram & 112,5 gram & 75 gram \\
Sedang & & & & \\
Tempe kedelai & - & 100 gram & 137,5 gram & 175 gram \\
Tepung tapioka & 10 gram & 10 gram & 10 gram & 10 gram \\
Margarin & 75 gram & 75 gram & 75 gram & 75 gram \\
Telur ayam & 60 gram & 60 gram & 60 gram & 60 gram \\
Garam & 5 gram & 5 gram & 5 gram & 5 gram \\
Keju cheddar & 50 gram & 30 gram & 30 gram & 30 gram \\
\hline
\end{tabular}

Sumber: Sulistyowati (2017) dan Modifikasi Peneliti

\subsection{Data Penelitian}

Penelitian stik keju tempe dengan perbandingan jumlah tepung terigu dan tempe kedelai yang berbeda dilakukan penelitian yang mencakup uji mutu hedonik dan uji hedonik (tingkat kesukaan). Uji mutu hedonik dan uji hedonik (tingkat kesukaan) meliputi warna, rasa 
dan tekstur dengan menggunakan instrumen berupa lembar penilaian dengan rentang skor 15 .

\subsection{Analisis Data Penelitian}

Penelitian stik keju tempe dianalisis secara statistik menggunakan one way ANOVA. Apabila hasil one way ANOVA menunjukkan adanya perbedaan, maka dilanjutkan dengan Duncan Multiple Range (DMRT) untuk mengetahui adanya perbedaan masing-masing perlakuan.

\section{Hasil dan Pembahasan}

\subsection{Hasil}

\subsubsection{Mutu Hedonik Warna}

Hasil rerata skor mutu hedonik warna stik keju tempe dapat dilihat pada Gambar 1 berikut:

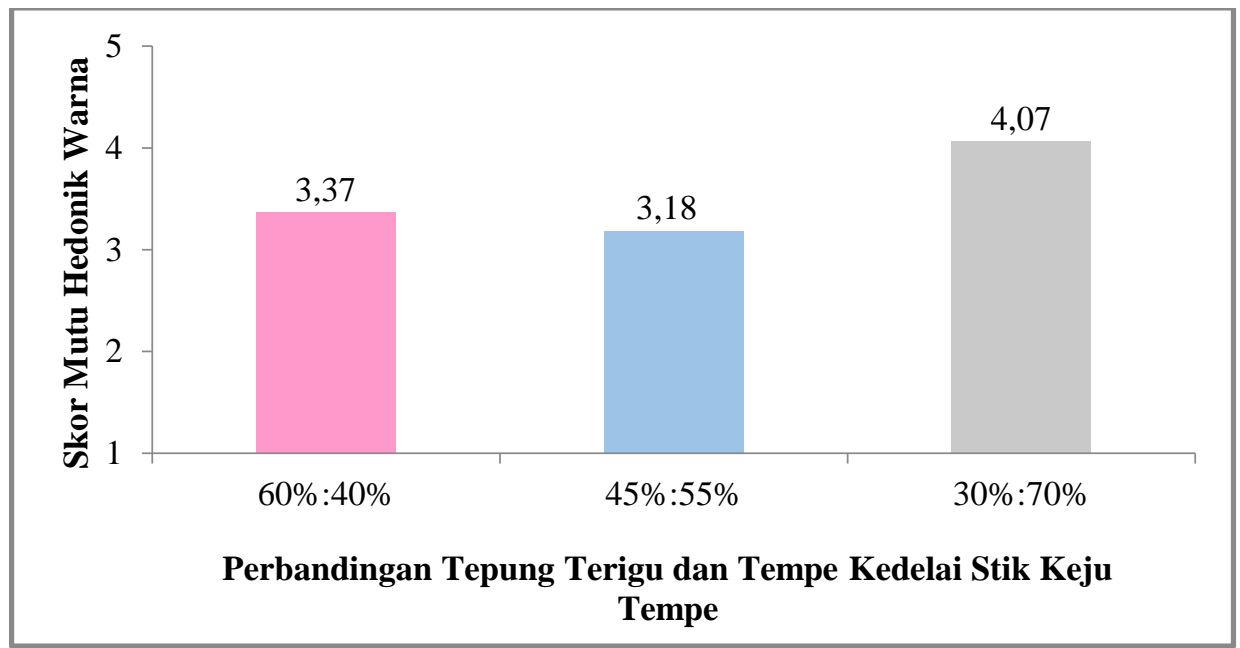

Gambar 1. Grafik Rerata Skor Mutu Hedonik Warna Stik Keju Tempe

Gambar 1 menunjukkan bahwa skor mutu hedonik warna stik keju tempe dengan perbandingan jumlah tepung terigu dan tempe kedelai 30\%:70\% memiliki skor tertinggi yaitu 4,07 (cukup cerah). Skor mutu hedonik warna stik keju tempe dengan perbandingan jumlah tepung terigu dan tempe kedelai 60\%:40\% dan 45\%:55\% memiliki skor 3,37 dan 3,18 yaitu agak cerah.

\subsubsection{Mutu Hedonik Rasa}

Hasil rerata skor mutu hedonik rasa stik keju tempe dapat dilihat pada Gambar 2 berikut: 


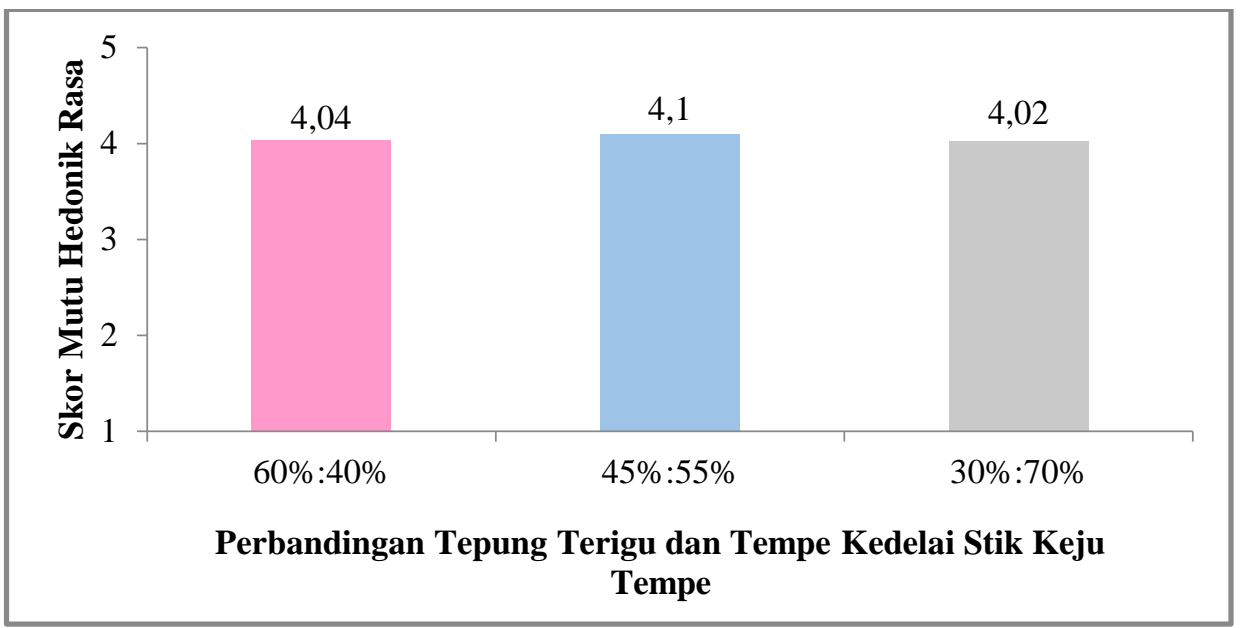

Gambar 2. Grafik Rerata Skor Mutu Hedonik Rasa Stik Keju Tempe

Gambar 2 menunjukkan bahwa skor mutu hedonik rasa stik keju tempe dengan perbandingan jumlah tepung terigu dan tempe kedelai 45\%:55\% memiliki skor tertinggi yaitu 4,1 (cukup gurih). Skor mutu hedonik rasa stik keju tempe dengan perbandingan jumlah tepung terigu dan tempe kedelai 60\%:40\% dan 30\%:70\% memiliki skor 4,04 dan 4,02 yaitu cukup gurih.

\subsubsection{Mutu Hedonik Tekstur}

Hasil rerata skor mutu hedonik rasa stik keju tempe dapat dilihat pada Gambar 3 berikut:

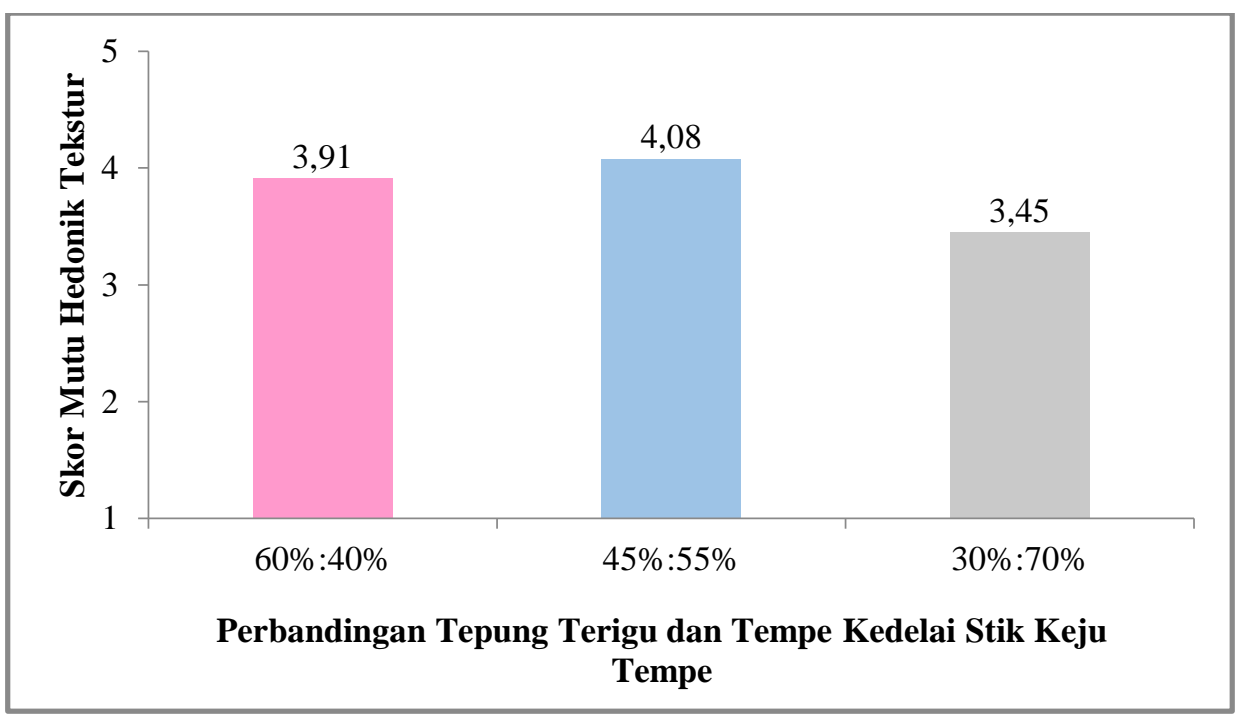

Gambar 3. Grafik Rerata Skor Mutu Hedonik Tekstur Stik Keju Tempe

Gambar 3 menunjukkan bahwa skor mutu hedonik tekstur stik keju tempe dengan perbandingan jumlah tepung terigu dan tempe kedelai 45\%:55\% memiliki skor tertinggi yaitu 4,08 (cukup renyah). Skor mutu hedonik tekstur stik keju tempe dengan perbandingan jumlah tepung terigu dan tempe kedelai 60\%:40\% dan 30\%:70\% memiliki skor 3,91 dan 3,45 yaitu agak renyah. 
Skor mutu hedonik warna stik keju tempe dengan perbandingan jumlah tepung terigu dan tempe kedelai 60\%:40\% dan 45\%:55\% memiliki skor 3,37 dan 3,18 yaitu agak cerah.

\subsubsection{Tingkat Kesukaan (Hedonik) Warna}

Hasil rerata skor hedonik (tingkat kesukaan) rasa stik keju tempe dapat dilihat pada Gambar 4 berikut:

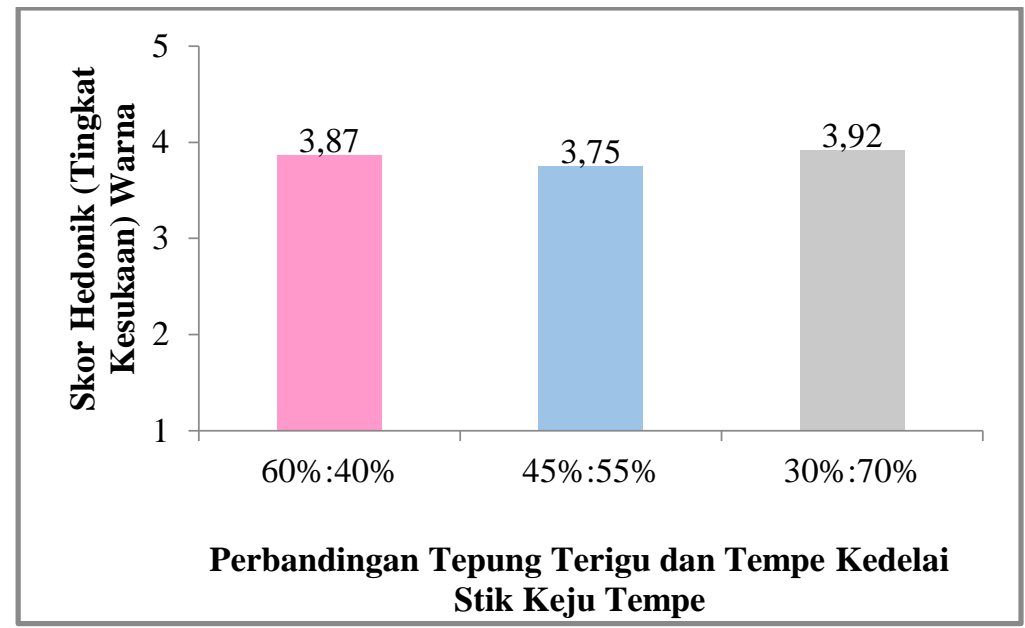

\section{Gambar 4. Grafik Rerata Skor Hedonik (Tingkat Kesukaan) Warna Stik Keju Tempe}

Gambar 4 menunjukkan bahwa skor hedonik (tingkat kesukaan) warna stik keju tempe dengan perbandingan jumlah tepung terigu dan tempe kedelai 30\%:70\% memiliki skor tertinggi yaitu 3,92 (biasa). Skor hedonik (tingkat kesukaan) warna stik keju tempe dengan perbandingan jumlah tepung terigu dan tempe kedelai 60\%:40\% dan 45\%:55\% memiliki skor 3,87 dan 3,75 yaitu biasa.

\subsubsection{Tingkat Kesukaan (Hedonik) Rasa}

Hasil rerata skor hedonik (tingkat kesukaan) rasa stik keju tempe dapat dilihat pada Gambar 5 berikut:

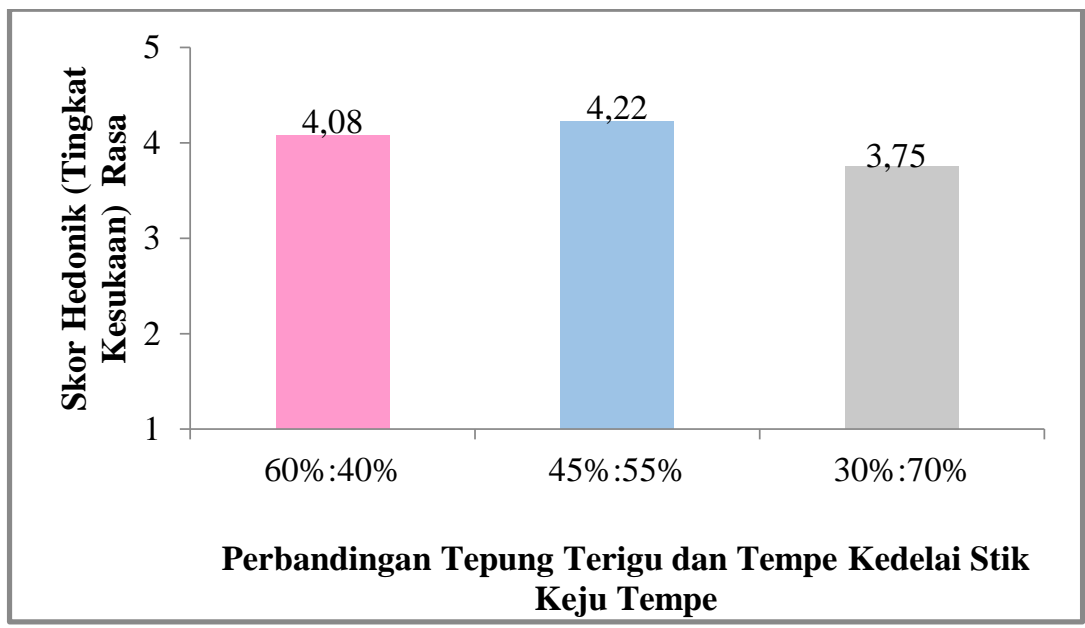

Gambar 5. Grafik Rerata Skor Hedonik (Tingkat Kesukaan) Rasa Stik Keju Tempe 
Gambar 5 menunjukkan bahwa skor hedonik (tingkat kesukaan) rasa stik keju tempe dengan perbandingan jumlah tepung terigu dan tempe kedelai 45\%:55\% memiliki skor tertinggi yaitu 4,22 (agak suka). Skor hedonik (tingkat kesukaan) rasa stik keju tempe dengan perbandingan jumlah tepung terigu dan tempe kedelai 30\%:70\% dan 60\%:40\% memiliki 3,75 biasa hingga agak suka.

\subsubsection{Tingkat Kesukaan (Hedonik) Tekstur}

Hasil rerata skor hedonik (tingkat kesukaan) tekstur stik keju tempe dapat dilihat pada Gambar 6 berikut:

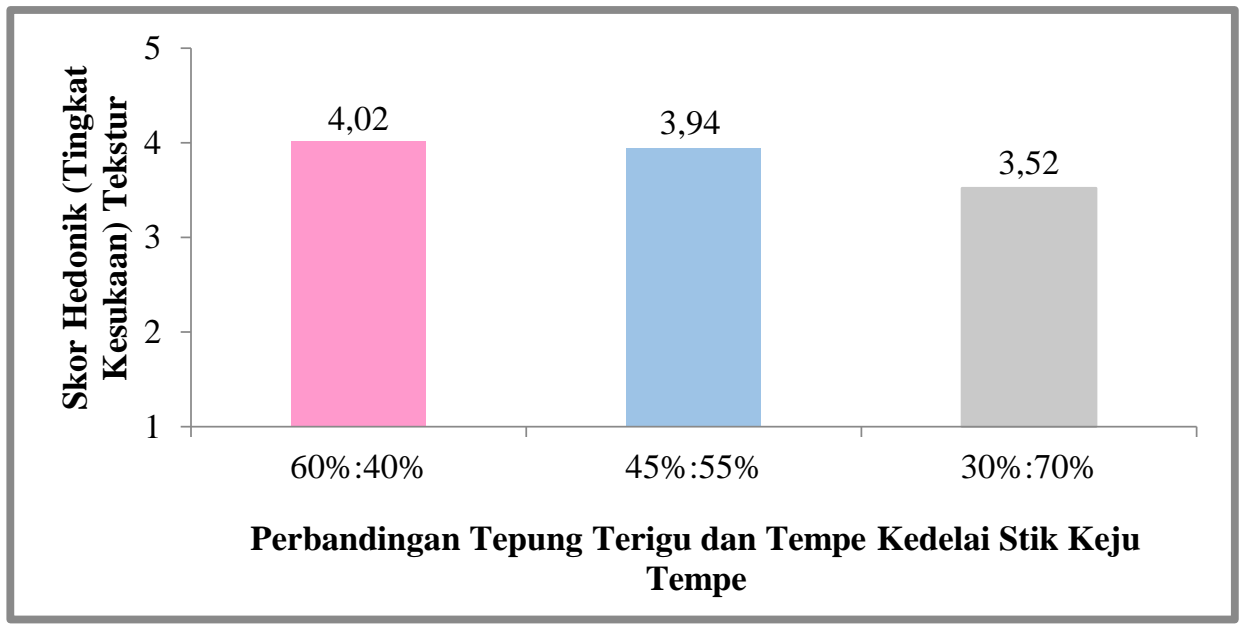

\section{Gambar 6 Grafik Rerata Skor Hedonik (Tingkat Kesukaan) Tekstur Stik Keju Tempe}

Gambar 6 menunjukkan bahwa skor hedonik (tingkat kesukaan) tekstur stik keju tempe dengan perbandingan jumlah tepung terigu dan tempe kedelai 60\%:40\% memiliki skor tertinggi yaitu 4,02 (agak suka). Skor hedonik (tingkat kesukaan) tekstur stik keju tempe dengan perbandingan jumlah tepung terigu dan tempe kedelai 45\%:55\% dan 30\%:70\% memiliki skor 3,94 dan 3,52 yaitu biasa.

\subsection{Pembahasan}

\subsubsection{Mutu Hedonik Warna}

Warna stik keju tempe dengan perbandingan tepung terigu dan tempe yang berbeda menunjukkan hasil yang berbeda nyata. Perbandingan tepung terigu dan tempe 30\%: 70\% memberikan warna yang lebih cerah daripada perlakuan yang lain. Perbedaan warna ini diduga akibat terjadinya reaksi Maillard. Menurut Winarno (2008) reaksi Maillard adalah reaksi pencoklatan non enzimatik antara karbohidrat dan protein.

Pada penelitian ini, tempe mensubstitusi tepung terigu. Kandungan karbohidrat tepung terigu lebih tinggi daripada kandungan karbohidrat tempe. Kandungan karbohidrat tepung terigu adalah 77,2\% dan kandungan karbohidrat pada tempe sebesar 13,5\% (Departemen Kesehatan, 2018). Penggunaan tempe yang lebih banyak menghasilkan produk dengan jumlah karbohidrat lebih sedikit dibandingkan produk lain. Tempe yang digunakan pada perlakuan 
sebanyak 70\% mengakibatkan reaksi Maillard yang terjadi lebih sedikit sehingga menimbulkan warna yang lebih cerah.

\subsubsection{Mutu Hedonik Rasa}

Rasa stik keju tempe dengan perbandingan tepung terigu dan tempe yang berbeda menunjukkan hasil yang tidak berbeda nyata. Perbandingan jumlah tepung terigu dan tempe kedelai yang berbeda pada stik keju tempe menghasilkan rentang skor mutu hedonik 4,024,04 yaitu cukup gurih. Menurut Kusnandar (2010) rasa gurih pada makanan disebabkan oleh asam amino glutamat. Glutamat merupakan bagian dari protein. Bahan-bahan yang mengandung protein yaitu tempe, keju dan telur. Menurut deMan (1997), kandungan asam glutamat gluten gandum sebanyak $36 \%$.

Pada penelitian ini, tempe mensubtitusi tepung terigu. Kandungan protein tempe lebih tinggi daripada kandungan protein pada tepung terigu. Penggunaan tempe yang lebih banyak menghasilkan produk dengan jumlah protein lebih banyak dibandingkan produk lain. Tempe yang digunakan pada perlakuan sebanyak $55 \%$ menghasilkan rasa pada stik keju tempe menjadi lebih gurih. Kandungan protein tempe sebanyak 20,8 gram, sedangkan kandungan protein tepung terigu sebanyak 9 gram (Departemen Kesehatan, 2018).

\subsubsection{Mutu Hedonik Tekstur}

Tekstur stik keju tempe dengan perbandingan tepung terigu dan tempe yang berbeda menunjukkan hasil yang berbeda nyata. Perbandingan tepung terigu dan tempe 45\%:55\% memberikan tekstur yang lebih renyah daripada perlakuan yang lain. Perbedaan tekstur ini diduga akibat kandungan karbohidrat.

Pada penelitian ini, penggunaan tempe sebagai pengganti tepung terigu pada stik keju tempe mempengaruhi tekstur pada stik keju tempe. Menurut Desrosier (2016) tepung terigu berfungsi sebagai pengikat di dalam semua formula kue kering. Semakin banyak tempe yang digantikan mempengaruhi tekstur pada stik keju tempe. Hal ini disebabkan karena kandungan karbohidrat pada tempe lebih sedikit dibandingkan dengan kandungan karbohidrat pada tepung terigu. Sehingga menyebabkan hasil produk menjadi rapuh dan gampang patah karena tempe tidak mampu mengikat.

\subsubsection{Tingkat Kesukaan (Hedonik) Warna}

Tingkat kesukaan warna stik keju tempe dengan perbandingan tepung terigu dan tempe kedelai yang berbeda menunjukkan hasil yang tidak berbeda nyata. Berdasarkan hasil penelitian yang diperoleh menunjukkan bahwa tingkat kesukaan warna pada stik keju tempe memiliki rentang skor 3,75-3,92 yaitu biasa. Hasil uji sifat mutu hedonik rasa stik keju tempe dengan perbandingan jumlah tepung terigu dan tempe kedelai 30\%:70\% menghasilkan warna yang cukup cerah.

\subsubsection{Tingkat Kesukaan (Hedonik) Rasa}

Tingkat kesukaan rasa stik keju tempe dengan perbandingan tepung terigu dan tempe kedelai yang berbeda menunjukkan hasil yang berbeda nyata. Berdasarkan hasil penelitian tingkat kesukaan rasa stik keju tempe dengan perbandingan tepung terigu dan tempe kedelai 
45\%:55\% adalah yang paling disukai dengan skor 4,22. Hasil uji sifat mutu hedonik rasa stik keju tempe dengan perbandingan jumlah tepung terigu dan tempe kedelai 45\%:55\% menghasilkan rasa yang cukup gurih.

\subsubsection{Tingkat Kesukaan (Hedonik) Tekstur}

Tingkat kesukaan tekstur stik keju tempe dengan perbandingan tepung terigu dan tempe kedelai yang berbeda menunjukkan hasil yang berbeda nyata. Berdasarkan hasil penelitian tingkat kesukaan tekstur stik keju tempe dengan perbandingan tepung terigu dan tempe kedelai 60\%:40\% adalah yang paling disukai dengan skor 4,02. Hasil uji sifat mutu hedonik stik keju tempe dengan perbandingan jumlah tepung terigu dan tempe kedelai 45\%:55\% menghasilkan tekstur yang cukup gurih.

\section{Simpulan}

Berdasarkan penelitian dapat disimpulkan bahwa terdapat perbedaan yang nyata pada mutu hedonik warna dan tekstur stik keju tempe dengan perbandingan tepung terigu dan tempe yang berbeda, sedangkan mutu hedonik rasa stik keju tempe tidak berbeda yang nyata. Warna stik keju tempe yang paling cerah didapatkan dari perlakuan 30\%:70\%, sedangkan pada tekstur stik keju tempe yang paling renyah didapatkan dari perlakuan 45\%:55\%. Terdapat perbedaan yang nyata terhadap tingkat kesukaan rasa dan tekstur stik keju tempe dengan perbandingan tepung terigu dan tempe yang berbeda, sedangkan tingkat kesukaan warna stik keju tempe tidak berbeda nyata. Tingkat kesukaan rasa yang paling disuka panelis didapatkan dari perlakuan 45\%:55\%, sedangkan tingkat kesukaan tekstur yang paling disuka panelis didapatkan dari perlakuan 60\%:40\%.

\section{Daftar Rujukan}

Badan Standardisasi Nasional, (2015). Tentang SNI Tempe Kedelai (SNI 3144:2015), Jakarta.

De-Man, J. M. (1997). Kimia Makanan. Bandung:ITB

Desrosier, N. W. (2016). Teknologi Pengawetan Pangan. Jakarta:UI-Press

Direktorat Jenderal Kesehatan Masyarakat. (2018). Tabel Komposisi Pangan Indonesia 2017. Jakarta:Kementerian Kesehatan Republik Indonesia.

Kusnandar, F. (2010). Kimia Pangan komponen Makro. Jakarta:Dian Rakyat

Pratiwi. F. (2013). Pemanfaatan Tepung Daging Ikan Layang Untuk Pembuatan Stick Ikan.

Sulistyowati, W. (2017). Cookingpreneur for Kids. Surakarta: Indiva Media Kreasi.

Winarno, F. G. (2008). Kimia Pangan dan Gizi. Bogor:M-BRIO Press 